\title{
Heating Characteristics of Developed Rectangular Resonant Cavity Applicator for Non-contact Hyperthermia Treatments
}

\author{
YASUHITO ICHISHIMA ${ }^{1 *}$, YASUHIRO SHINDO ${ }^{2}$, YUYA ISEKI ${ }^{3}$, KAZUO KATO $^{4}$ \\ ${ }^{1}$ Graduate School of Science Technology, Meiji University, 1-1-1 Higashi-Mita, Tama, Kawasaki 214-8571, \\ Japan \\ ${ }^{2}$ Faculty of Science \& Engineering, Toyo University, 2100 Kujirai, Kawagoe, Saitama 350-8585, Japan \\ ${ }^{3}$ Department of Mechanical Engineering, Hachinohe National College of Technology, 16-1 Uwanotai, \\ Tamonoki, Aomori 039-1192, Japan \\ ${ }^{4}$ Department of Mechanical Engineering Informatics, Meiji University, 1-1-1 Higashi-Mita, Tama, Kawasaki \\ 214-8571, Japan
}

\begin{abstract}
In our previous study, a non-invasive heating method was proposed which could utilize a re-entrant type resonant cavity applicator for deep-seated tumors. For the first time, a prototype heating system using a cylindrical resonant cavity applicator was developed, and results from the experimental heating of agar phantoms and animals were discussed. In the proposed method, as a whole human body was set in the cylindrical resonant cavity applicator to heat the targeted area, there was a risk of heating healthy human tissues.

In the present paper, a new method using a rectangular resonant cavity is proposed to non-invasively heat the targeted area without physical contact to the subject. Dimensions of the rectangular resonant cavity applicator were $60 \mathrm{~cm}$ in height, $70 \mathrm{~cm}$ in width and $20 \mathrm{~cm}$ in length. In this method, since the targeted area is placed inside the rectangular resonant cavity applicator, the risk of heating the healthy tissue is minimized.

Here, the measured temperature distributions of the heated agar phantom with the developed system was described. First, a setup of the proposed resonant cavity applicator was presented. Second, the results of heating human shaped agar phantom were presented. Finally, the results of computer simulations and experiments with the developed prototype heating system were discussed.

From these results, it was found that the proposed rectangular resonant cavity applicator could be useful in controlling a small heated area without contact to the human body, and could be applicable for treating various tumors.
\end{abstract}

Key Words: hyperthermia, rectangular resonant cavity applicator, non-contact hyperthermia

Received 21 November, 2018, Accepted 22 December, 2018: *Corresponding author; Tel, 09043804678;

e-mail, yasuhitoichishima@gmail.com

doi: $10.3191 /$ thermalmed.35.1

2019 Japanese Society for Thermal Medicine 


\section{緒言}

電磁波ハイパーサーミアは，副作用の少ない癌の温熱治療法として注目されており，これまでに種々 の電磁波加温方式が提案されているが, 脂肪層の高温化, 目的部位以外での異常加温, 疼痛などの問題 点が多く, 未だに決定的な装置の開発には至っていないのが現状である。このような問題に対し, 著者 らは，これまでにマイクロ波の分野でよく知られている円筒形状の空胴共振器を応用した非接触型の加 温装置を提案している ${ }^{1-10)}$. 有限要素法によるコンピュータシミュレーション，拈よびこのシミュ レーション結果に基づく加温システムを試作し，寒天ファントムおよび動物の加温実験を通して，その 有効性を実証してきた 2-4). 最近では, この加温方式を応用した小型空胴共振器加温システムを開発し, 変形性膝関節症の臨床研究を開始している ${ }^{10)}$. しかしながら, これらの空胴共振器加温システムでは, 円筒型空胴共振器内に収まる人体の範囲が広いため, 例えば人体腹部の深部腫瘍を非接触状態で加温し ようとした場合, あるいは変形性膝関節症の電磁波温熱治療に際して, 空胴共振器内に収まっている目

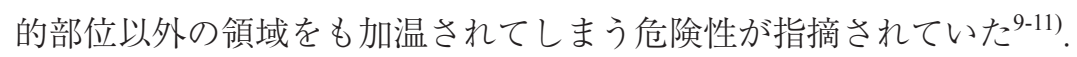

本研究では, これまでの円筒型空胴共振器アプリケータの欠点を補うために, 矩形状の空胴共振器を 用いた矩形型空胴共振器アプリケータを提案している. Fig. 1 に, 円筒形状および矩形状の空胴共振器 を用いた加温イメージ図を示す．Fig. 1b に示す矩形型空胴共振器を用いれば，Fig. 1a の円筒型空胴共 振器とは異なり，共振器内に収まる人体の範囲は少なくなり，そのため目的部位近傍のみを加温できる 可能性があると考えられる, 本論文では, 試作した矩形型空胴共振器の形状, 加温システムの概要, お よび本加温システムを用いて, 人体形状寒天ファントムを加温した結果を示し, 本手法の有用性を明ら かにする.

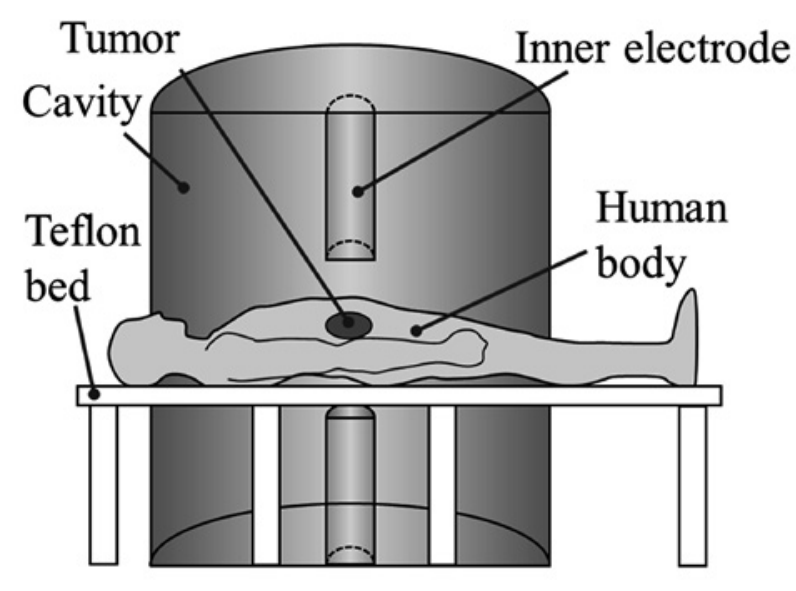

$a$

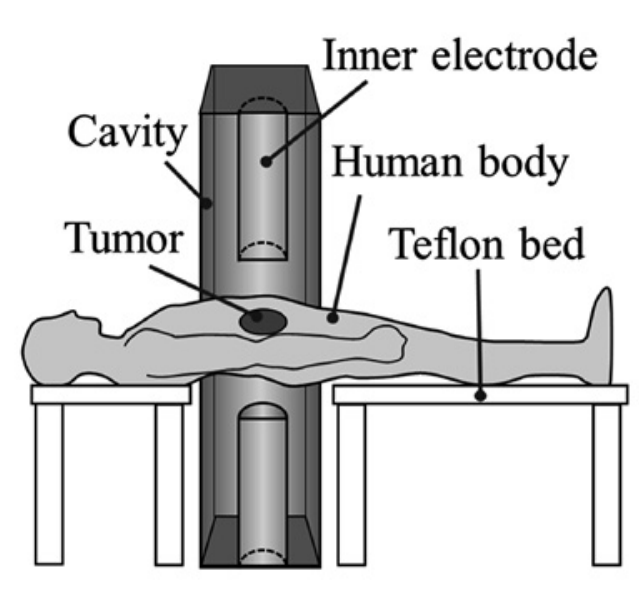

$b$

Fig. 1. Illustration of developed systems. $a$, Cylindrical resonant cavity applicator. $\boldsymbol{b}$, Rectangular resonant cavity applicator. 


\section{材料と方法}

矩形型空胴共振器

試作した矩形型空胴共振器の形状および寸法を決定するために有限要素法（FEM）による数值解析 を行った．なお，ここでは紙面の都合上，FEM 計算手法等についての詳細を省略する2),5),8),99. Fig. 2 は, FEM 計算モデルを作成するに際して行った，人体形状寒天ファントムの超音波画像を撮像するための 概念図である ${ }^{12}$. Fig. 2 に示すように, 加温対象物を水中に沈め, 全体像が取り込めるように, コンベッ クスプローブ（超音波画像診断装置＼cjkstart東芝メディカルシステムズ社：Nemio SSA-550A，東京）を用い て, $10 \mathrm{~mm}$ 間隔で計 51 枚の超音波画像を撮像した. Fig. 3 は，撮像した超音波画像から作成した FEM 計算モデルの一例である ${ }^{12)}$ 。このモデルを用いた FEM解析を実施し, 矩形型空胴共振器の寸法, パ ワーゼネレータの周波数レンジ等を決定した.

Fig. 4 は, 試作した矩形型空胴共振器およびその寸法である. 本共振器の寸法は, 高さ $: 60 \mathrm{~cm}$, 横幅： $70 \mathrm{~cm}$, 厚さ : $20 \mathrm{~cm}$, 総重量 : $25 \mathrm{~kg}$, アルミニウム製であり, 高導電性を確保するために主要なつな ぎ目には,アルミニウム溶接を施した。

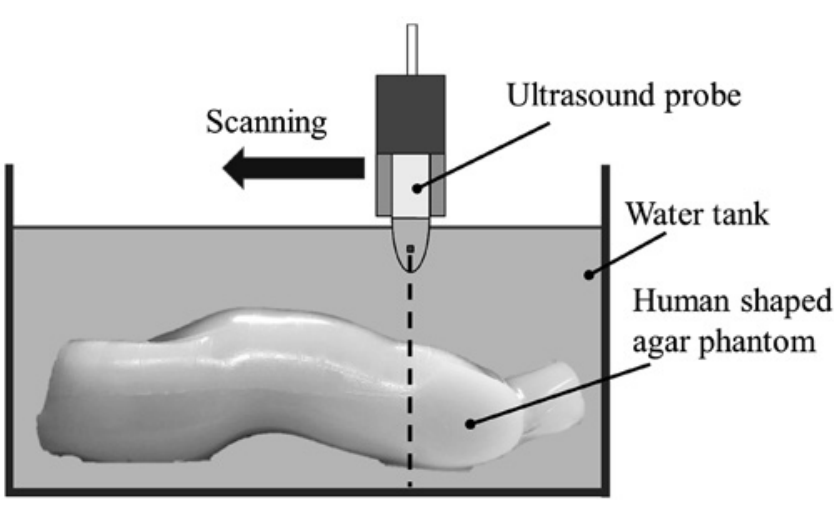

Fig. 2. Method of scanning ultrasound images.

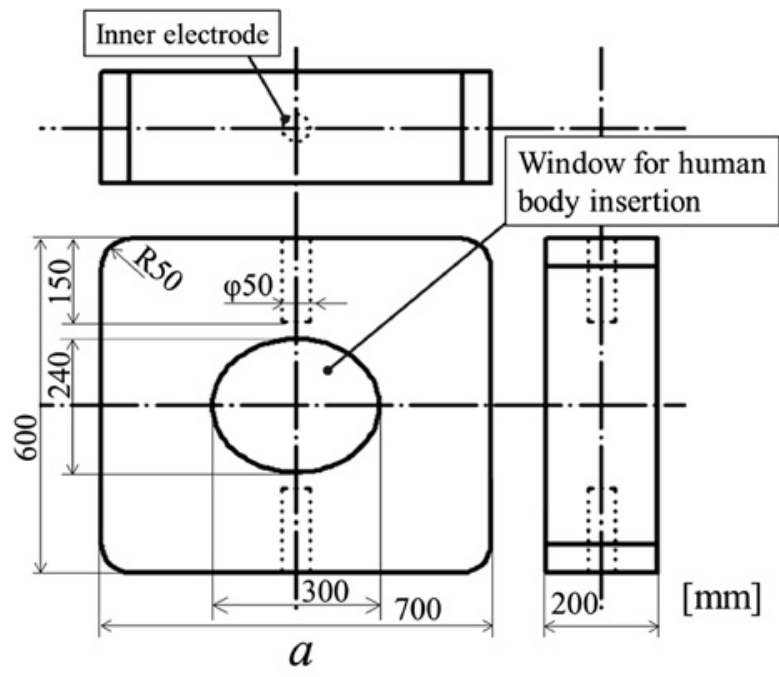

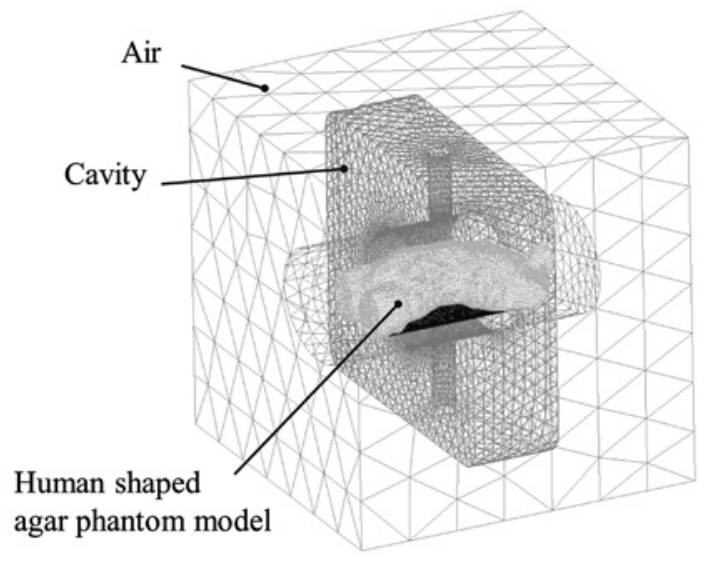

Fig. 3. Model for FEM calculation.

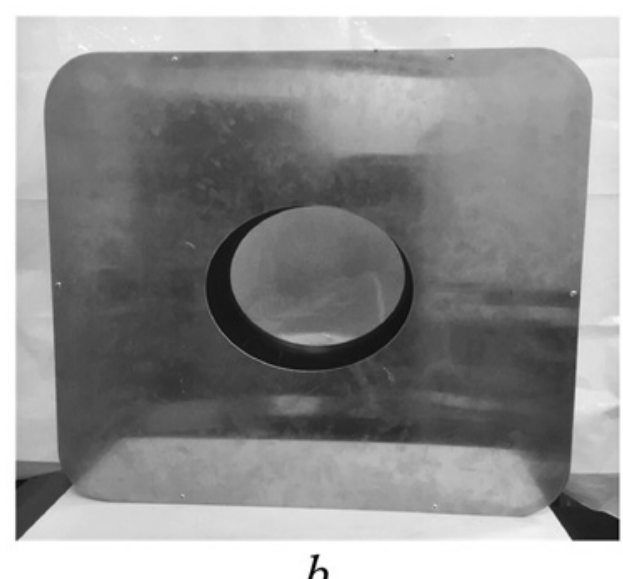

Fig. 4. Prototype rectangular resonant cavity applicator. $\boldsymbol{a}$, Dimensions of the rectangular resonant cavity applicator. $b$, Rectangular resonant cavity applicator. 


\section{広帯域高周波パワーゼネレータ}

矩形状の空胴共振器内に，その寸法に応じた共振周波数帯の高周波電力を供給するための広帯域高周 波パワーゼネレータを試作した。Fig. 5 は, 試作したパワーゼネレータ（JS 技研株式会社：特注, 埼玉)

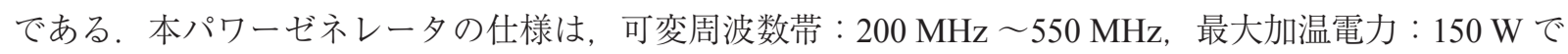
ある，な扔，本装置は，共振周波数の自動探索抢よび自動インピーダンス整合機能を有している，重量 は, $15 \mathrm{~kg}$ 程度であり，持ち運びが可能である.

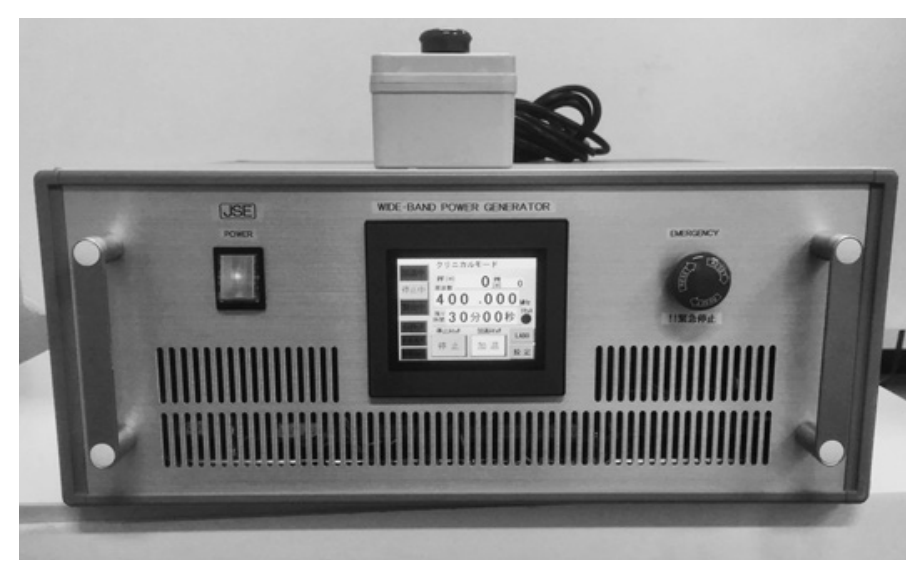

Fig. 5. High frequency amplifier.

\section{励振用アンテナ}

Fig. 6 は, 矩形状の空胴共振器内に電磁波を励振するための試作アンテナおよびアンテナ設置位置を 示す図である。ここでは銅板（厚さ：1 mm）を適宜切断し，そのアンテナ幅を $20 \mathrm{~mm}$ とした。アンテ ナ長については, 加温に使用する電磁波共振パターンに応じて, 選択する必要がある ${ }^{8)}$. 今回の加温実 験では, そのアンテナ長さを $130 \mathrm{~cm}$ 程度とした. Fig. $6 \mathrm{~b}$ のうに, このアンテナを共振器側面から $17.5 \mathrm{~cm}$ 離れた上面に設置した。

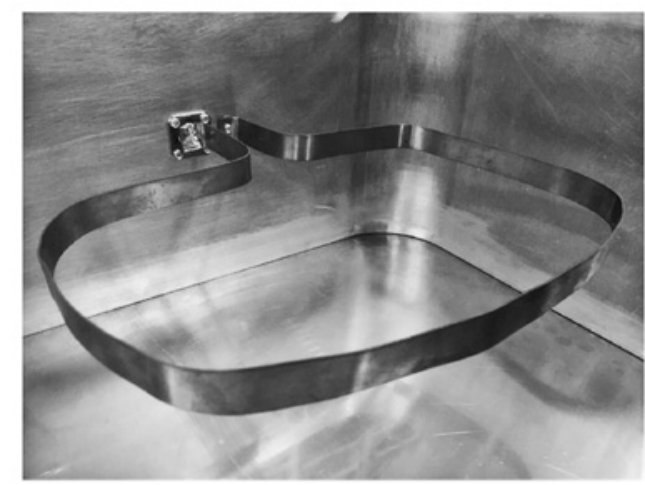

$a$

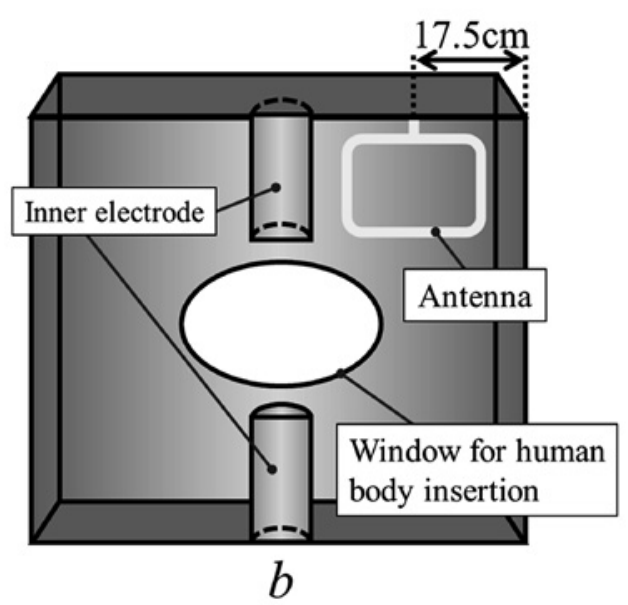

Fig. 6. Used antenna. 


\section{人体形状寒天ファントム}

Fig. 7 は, 加温実験に用いた人体形状の寒天ファ ントム（日本人男子 5 歳児程度の平均体型）である。 市販のプラスチックケース（ストア・エキスプレス オンラインショップ: 子供ラッカーボデイ 110 白 ラッカー）の中に, 熱湯（市販の飲料天然水）に溶 かした寒天を流し込み，人体形状を模擬した寒天 ファントムを成形した ${ }^{12}$ ） その概略寸法は，全長 （首部から太股までの長さ）：50 cm, 胸囲 $\mathrm{LB}$ ： $50 \mathrm{~cm}$, 胴囲 $\mathrm{LA}_{\mathrm{A}}: 55 \mathrm{~cm}$, 腰囲 $\mathrm{LH}: 60 \mathrm{~cm}$ である. なお, 寒天の物性值は周波数 $393.5 \mathrm{MHz}$ において は, 比誘電率: 78.556 , 電気伝導率 : $0.6010 \mathrm{~S} / \mathrm{m}$, 密度: $1000 \mathrm{~kg} / \mathrm{m}^{3}$, 周波数 $395.0 \mathrm{MHz}$ においては, 比誘電率 : 78.551 , 電気伝導率 $: 0.6012 \mathrm{~S} / \mathrm{m}$, 密度 : $1000 \mathrm{~kg} / \mathrm{m}^{3}$ である。

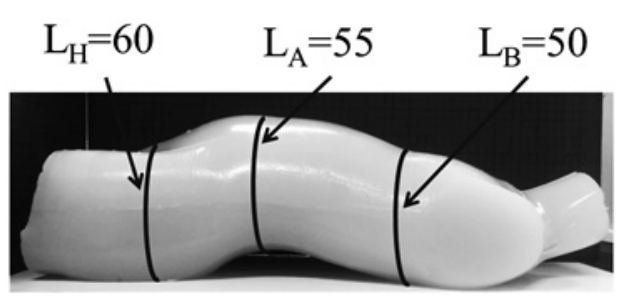

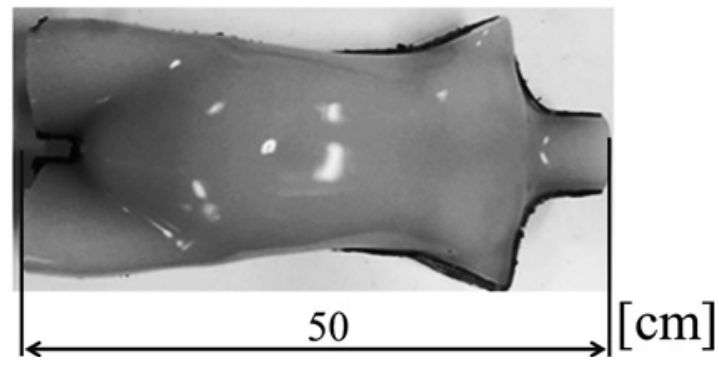

Fig. 7. Human shaped agar phantom.

\section{結果}

Fig. 8 は，加温実験時における人体形状寒天ファントムの配置図である. Fig. $8 \mathrm{a}$ および b に示すよう に, 人体形状寒天ファントムの 2 力所（図中の領域 $\mathrm{A}$ 抢よび領域 B) を加温ターゲットとした. 加温 前に Fig. 8 に示すように，予め，領域 A および領域 B を加温するために，それぞれの位置に寒天ファ ントムを設置した状態でネットワークアナライザー（Agilent Technologies 社：N9923A, 東京）を用い て，電圧反射係数を測定した。
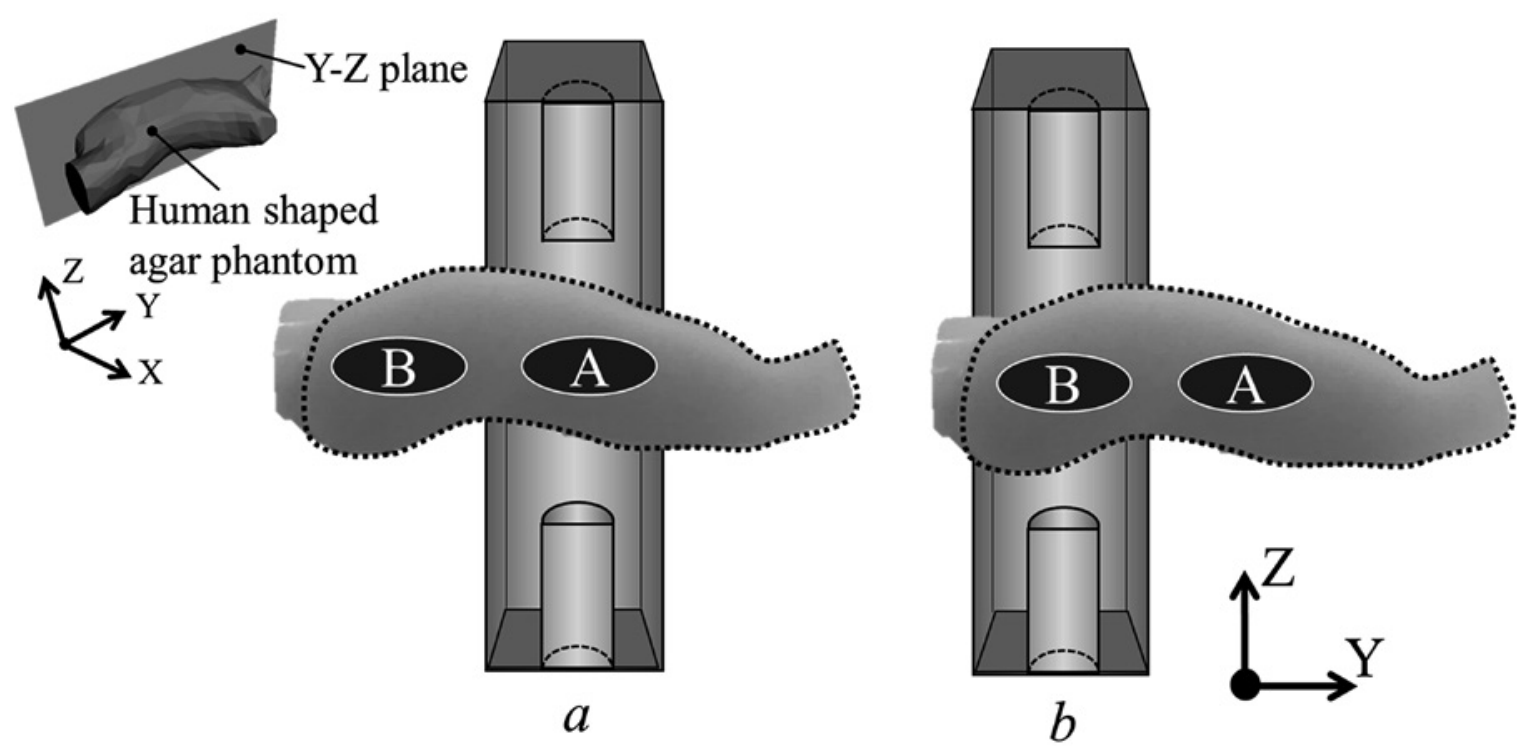

Fig. 8. Targeted area for heating (Y-Z plane). $\boldsymbol{a}$, Heated area A. $\boldsymbol{b}$, Heated area B. 
Fig. 9 に，その測定結果を示す. Fig. 9 から，いずれの場合にも， $390 \mathrm{MHz} \sim 400 \mathrm{MHz}$ の周波数带域 に打いて, それぞれの共振周波数の存在が確認でき, 試作したパワーゼネレータ (可変周波数帯： $200 \mathrm{MHz} \sim 550 \mathrm{MHz}$ ）を用いて加温可能であることが分かる．なお加温実験に際しては，いずれの場 合も, 加温電力： $50 \mathrm{~W}$, 臨床で使用されている $\mathrm{RF}$ 誘電加温装置では, 加温治療時間 : 30 60 分程度 であることを考慮し，ここでは加温時間：30 分とした，さらに図中の領域 A および B を加温した際の 詳細な共振周波数は，それぞれ， $393.5 \mathrm{MHz}$ および $395.0 \mathrm{MHz}$ であった。

Fig. 10 は, Fig. 8 に示した加温位置（領域 A およびB）における加温直後の寒天中央断面での赤外 線サーモ画像である. Fig. 10 から，いずれも目的とした加温領域が集中的に加温されており，他の領 域にホットスポットは発生していないことが確認できる.

Fig. 11 は，Fig. 10 に示した加温直後の寒天中央断面における赤外線サーモ画像から作成した温度上 昇プロファイルである。 Fig. 10a および b から，それぞれの最高温度上昇は， $5.3^{\circ} \mathrm{C}$ およ゙ $5.0^{\circ} \mathrm{C} て ゙ あ り ，$

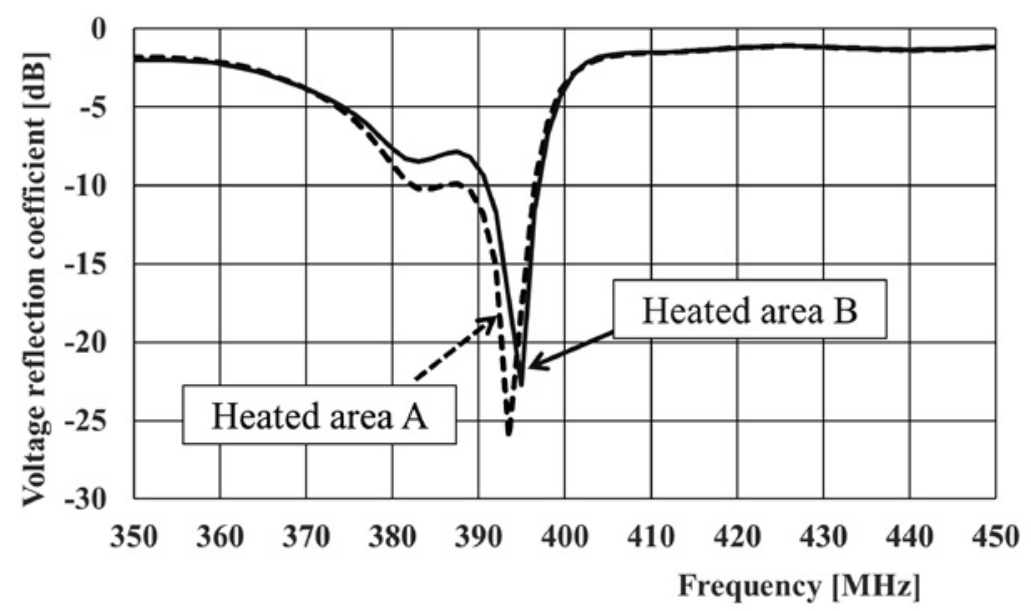

Fig. 9. Voltage reflection coefficient profiles.
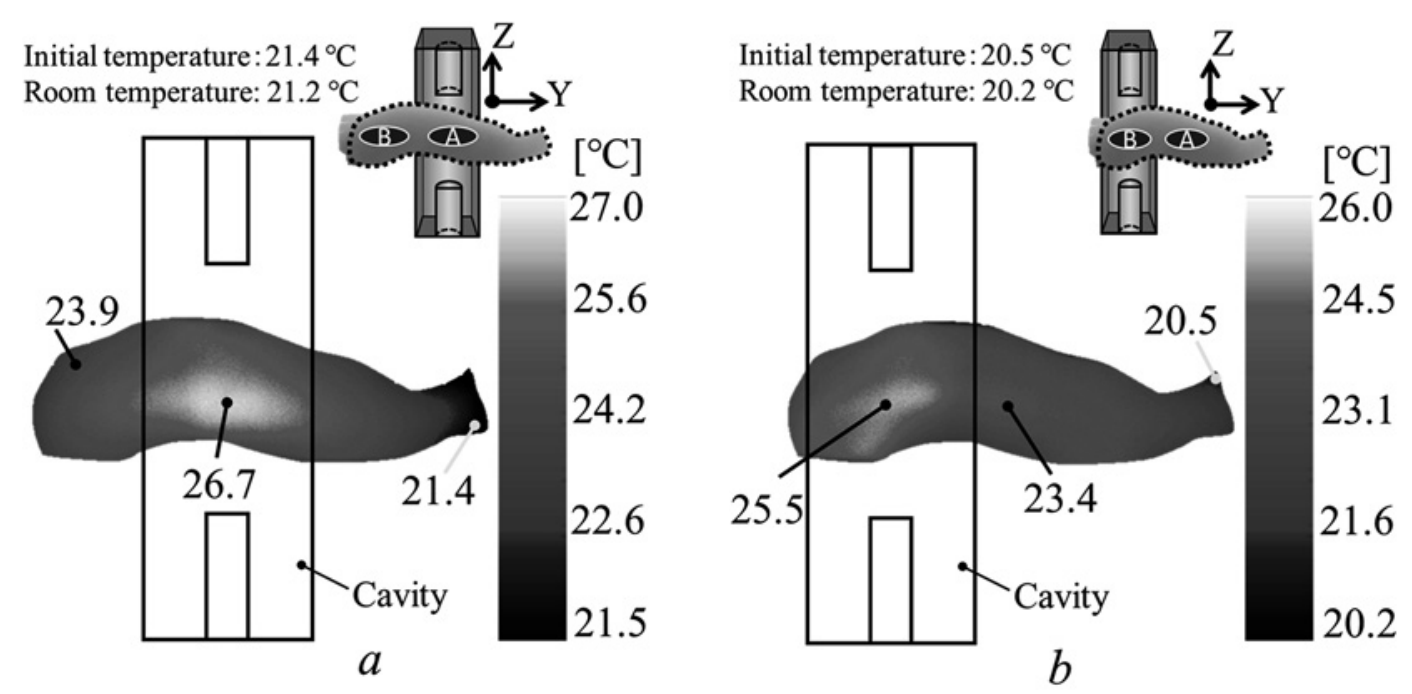

Fig. 10. Thermal images of heated agar phantom (Y-Z plane). $\boldsymbol{a}$, Heated area A. $\boldsymbol{b}$, Heated area B. 
本加温システムは高い加温性能を持つことが確認できる，血流の冷却効果により，本実験で得られたよ うな温度上昇が得られない可能性があるが，本パワーゼネレータは最大加温電力：150 Wで設計されて いるため, 患者を対象した場合においても，加温電力を上げれば，ハイパーサーミアに有効な温度上昇 が得られる可能性があると考えられる。

\section{考察}

まず，本矩形型空胴共振器を設計するために実施した FEM 解析結果と本加温実験結果との比較を考 察する. Fig. 12a は, Fig. 8 に示した領域 A を加温対象として, FEM 計算を実施した際の中央断面での 温度分布結果であり, Fig. 12b は, 本試作加温システムにより加温した寒天ファントムの同位置におけ る赤外線サーモ画像である。両者を比較すると, いずれも加温対象である領域 $\mathrm{A}$ が最高温度に加温さ れており，それ以外には，ホットスポットは発生していないことが分かる。 また，両者の加温パターン
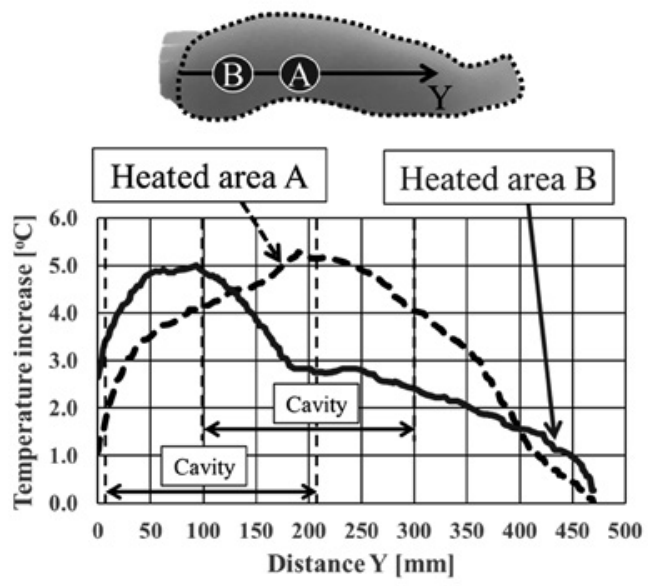

$a$
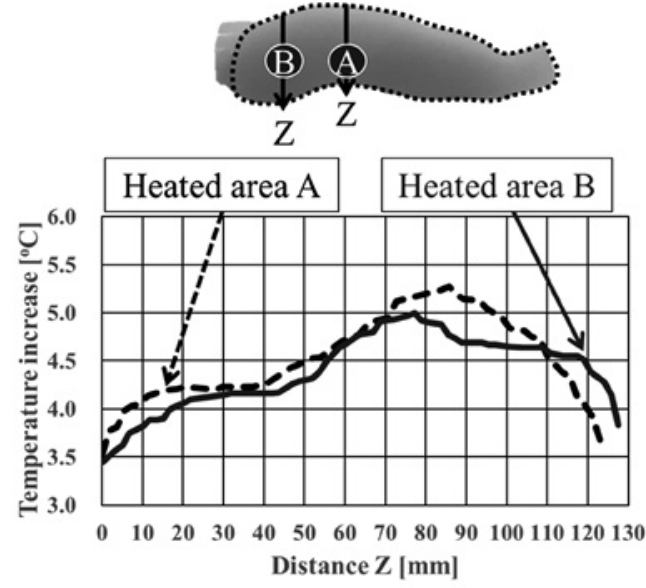

$b$

Fig. 11. Temperature increase profiles. $\boldsymbol{a}$, On the Y-axis. $\boldsymbol{b}$, On the Z-axis.

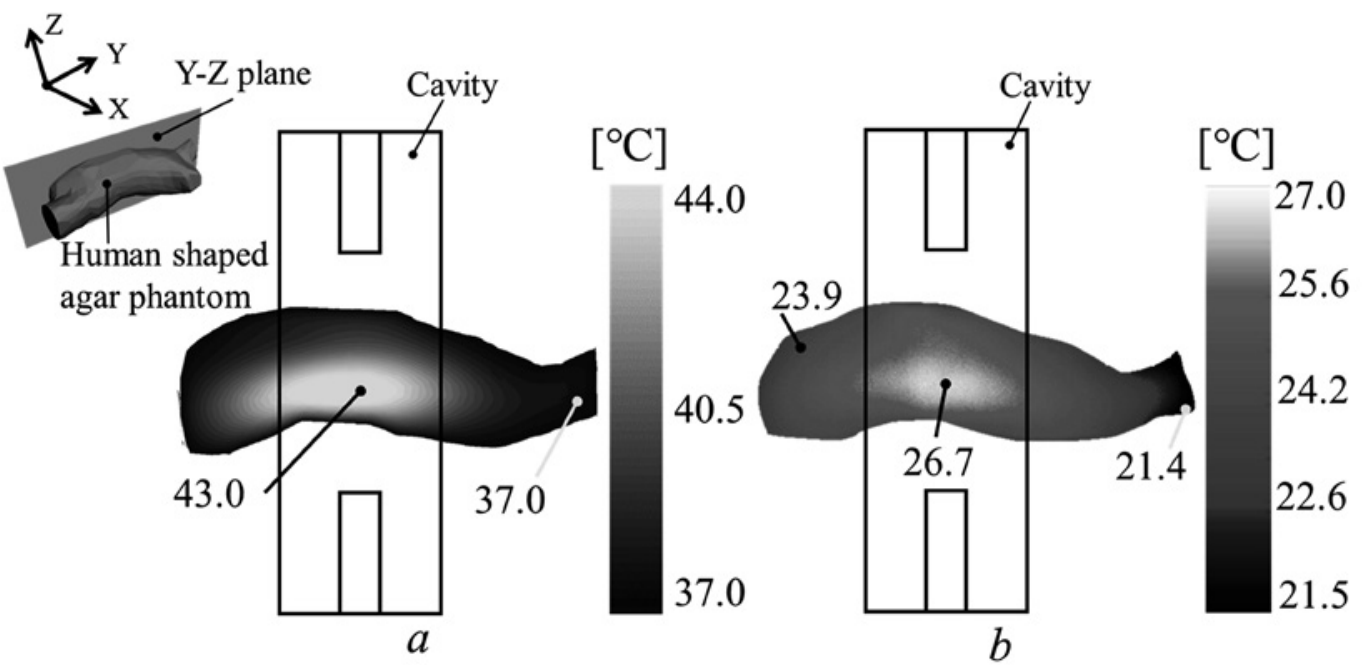

Fig. 12. Temperature distributions (Y-Z plane). $\boldsymbol{a}$, Estimated temperature distribution. $\boldsymbol{b}$, Thermal image of agar (Experiment A). 
も類似した結果であることが確認できる，さらに両者の有効加温領域の比較を行うために，以下の正規 化公式を用いて温度上昇值を無次元化する ${ }^{8-10)}$.

$$
\mathrm{T}=\frac{\mathrm{T}-\mathrm{T}_{\mathrm{MIN}}}{\mathrm{T}_{\mathrm{MAX}}-\mathrm{T}_{\mathrm{MIN}}}
$$

ここで, $\mathrm{T}_{\mathrm{N}}$ ：正規化温度上昇值, $\mathrm{T}_{\mathrm{MIN}}$ : 中央断面での最小温度上昇值 $\left({ }^{\circ} \mathrm{C}\right), \mathrm{T}_{\mathrm{MAX}}$ : 中央断面での最 大温度上昇值 $\left({ }^{\circ} \mathrm{C}\right), \mathrm{T}$ ：中央断面での任意の点の温度上昇值 $\left({ }^{\circ} \mathrm{C}\right)$ である.

以上の関係式を用いて求めた正規化温度上昇值を Fig. 13 㧍よびFig. 14 に示す。ここで, ハイ

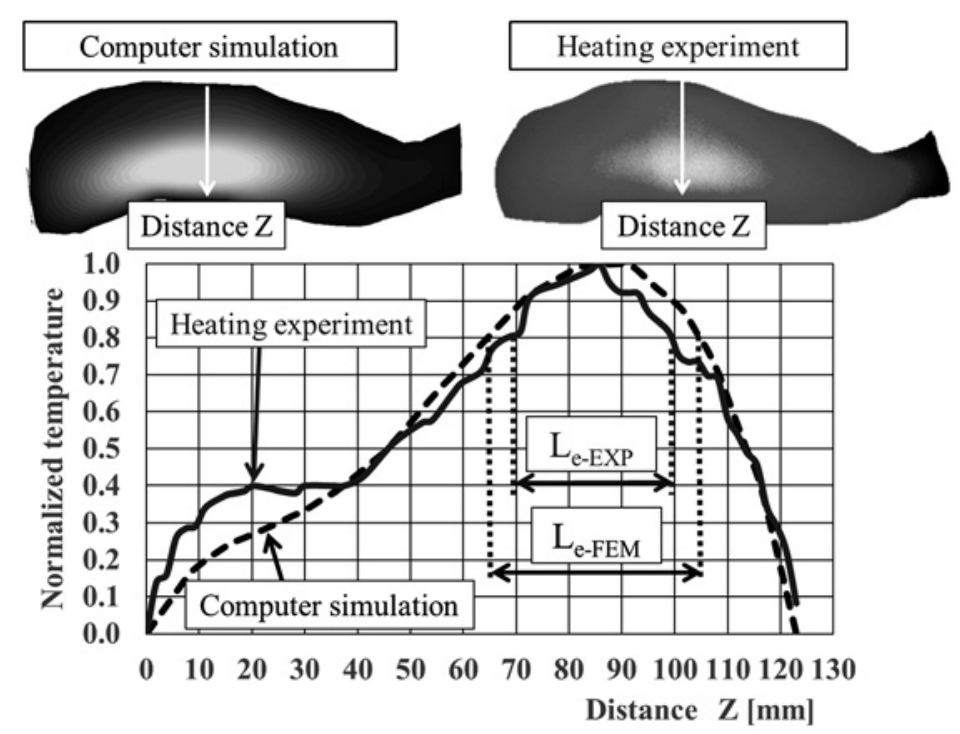

Fig. 13. Normalized temperature profiles.

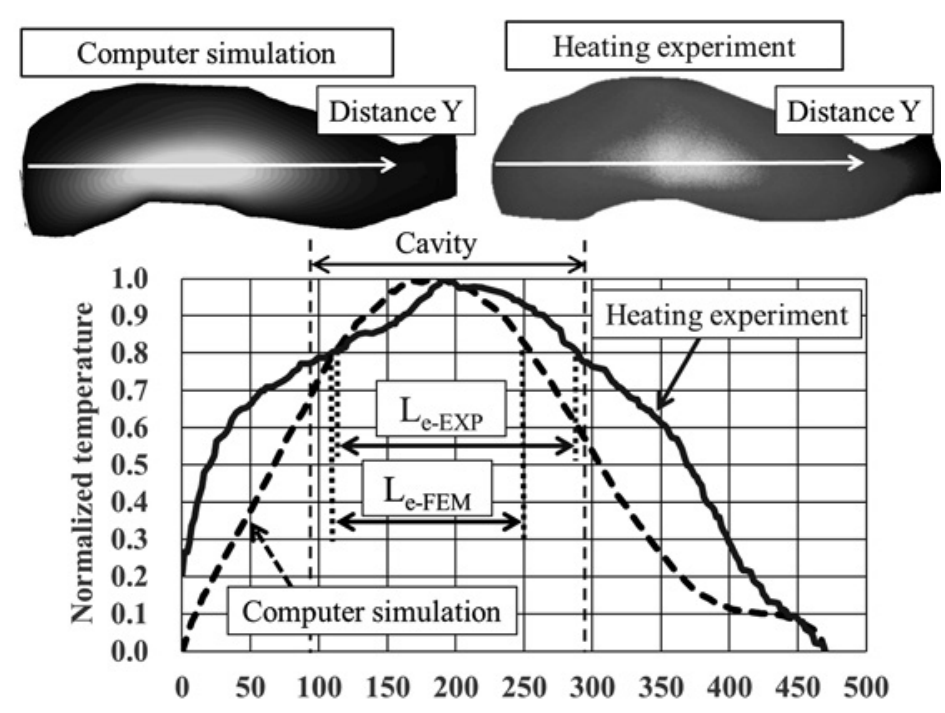

Fig. 14. Normalized temperature profiles. 
パーサーミアにおいて目的とする温度带は, $42-43^{\circ} \mathrm{C}$ であり, 人体組織の初期温度 $37^{\circ} \mathrm{C}$ を正規化温度值 0.0 , 最高温度 $43^{\circ} \mathrm{C}$ を正規化温度值 1.0 とすれば， $42^{\circ} \mathrm{C}$ のそれは 0.8 程度に相当する。このことから，正 規化温度プロファイルにおける有効加温領域長 $(\mathrm{Le})$ は, 正規化温度值 0.8 以上の領域に対応すると考 えられる. Fig. 13，14 中に示した FEM 解析結果の Z 軸方向の有効加温領域長は, Le-FEM $=39 \mathrm{~mm}$, 加 温実験結果のそれは, Le-EXP = $31 \mathrm{~mm}$ であり, Y 軸方向の有効加温領域長は, Le-FEM $=144 \mathrm{~mm}$, 加温実 験結果のそれは， Le-EXP $=179 \mathrm{~mm}$ であった。また最高温度上昇值の発生位置も極めて近く， Z 軸方向， $\mathrm{Y}$ 軸方向ともに，その誤差は $5 \%$ 程度内であり，本論文で実施した典型的な加温条件では良好な加温特 性であった，今後は, この結果を基に, 実際の人体モデルを作成し, 臨床研究への応用を計画している.

\section{結言}

本論文では, 従来の円筒型空胴共振器アプリケータの欠点を補うために, 矩形型空胴共振器アプリ ケータを提案し，FEM 解析およびこの結果に基づき試作した加温システムを用いた寒天ファントムの 加温実験を実施した。これらの結果から，人体深部領域を非接触状態で，局所的に加温できる可能性を 明らかにした，特に，矩形状の空胴共振器内に収まった加温対象領域のみが有効加温され，それ以外の 領域は異常加温されないことが確認された。

今回の検討では, 人体形状の均一な寒天ファントムを用いているが, 今後, 三次元人体モデルを用い たFEM 解析，および動物の加温実験を実施する予定である。さらに本加温システムに，本研究室で提 案している超音波画像を用いた非侵襲温度計測システムを組み合わせた，より安全性が高く，かつ効果 的なハイパーサーミアシステムを構築する予定である.

\section{謝辞}

本研究の一部は, JSPS 科研費（18H03553）の助成を受けたものである.

\section{参考文献}

1) Matsuda J., Kato K., Saitoh Y.: The application of a re-entrant type resonant cavity application to deep and concentrated hyperthermia. Jpn Hyperthermia Oncol, 4: 111-118, 1988. (Japanese)

2) Kato K., Yabuhara T., Wadamori N., Matsuda J.: Design and construction of resonant cavity applicator for deep tumor hyperthermia treatment without contact: Part 1: Analysis of temperature distribution by computer simulations. J Jpn Soc Des Eng, 39: 37-43, 2004. (Japanese)

3) Kato K., Wadamori N., Matsuda J., Takahashi H., Uzuka T., Tanaka R.: Design and construction of resonant cavity applicator for deep tumor hyperthermia treatment without contact: Part 2: Experimental heating results of agar phantom using developed heating system. J Jpn Soc Des Eng, 39: 44-49, 2004. (Japanese)

4) Kato K., Wadamori N., Matsuda J., Takahashi H., Uzuka T., Tanaka R.: Design and construction of resonant cavity applicator for deep tumor hyperthermia treatment without contact: Part 3: Experimental heating results of human shape agar phantom and animal using developed heating system. J Jpn Soc Des Eng, 39: 49-53, 2004. (Japanese)

5) Shigihara T., Kato K., Yabuhara T., Kohara T., Uzuka T., Takahashi H., Tanaka R.: Improvement of the resonant cavity applicator for brain tumor hyperthermia -Computer simulation results-. Conf Proc IEEE Eng Med Biol Soc, 2005: 220-223, 2005.

6) Yabuhara T., Kato K., Tsuchiya K., Shigihara T., Kohara T., Uzuka T., Takahashi H., Tanaka R.: Improvement of the resonant cavity applicator for brain tumor hyperthermia -Experimental heating results-. Conf Proc IEEE Eng Med Biol Soc, 2005: 
6777-6780, 2005.

7) Yabuhara T., Kato K., Tsuchiya K., Shigihara T., Kohara T., Uzuka T., Takahashi H.: Development of the re-entrant type resonant cavity applicator for brain tumor hyperthermia -Experimental heating results-. Conf Proc IEEE Eng Med Biol Soc, 2006: 5161-5164, 2006.

8) Yabuhara T., Shindo Y., Kato K., Takahashi H., Uzuka T., Fujii Y.: Heating properties of a resonant cavity applicator for brain tumor hyperthermia: TM-like modes permit heat production without physical contact. Thermal Med, 24: 141-152, 2008.

9) Shindo Y., Iseki Y., Yokoyama K., Arakawa J., Watanabe K., Kato K., Kubo M., Uzuka T., Takahashi H.: SAR analysis of the improved resonant cavity applicator with electrical shield and water bolus for deep tumors by a 3-D FEM. Conf Proc IEEE Eng Med Biol Soc, 2012: 5679-5682, 2012.

10) Shindo Y., Watanabe K., Iseki Y., Kato K., Kurosaki H., Takahashi K.: Heating properties of resonant cavity applicator for treatment of osteoarthritis -Temperature distributions calculated by 3-D FEM-. Thermal Med, 30: 1-12, 2014.

11) Shindo Y., Kato K., Ichishima Y., Iseki Y., Tokutake R., Ikuta F., Takahashi K.: Evaluation of deep thermal rehabilitation system using resonant cavity applicator during knee experiments. Conf Proc IEEE Eng Med Biol Soc, 2018: 3220-3223, 2018.

12) Nakamura K., Anan D., Matsushita T., Iseki Y., Shindo Y., Kato K., Uzuka T., Takahashi H.: Heating properties of the resonant cavity applicator with ultrasound monitoring system for effective hyperthermia treatments. Conf Proc EuCAP, 2015: 1570048195.PDF, 2015.

13) Iseki Y., Takahashi H., Uzuka T., Kato K.: A new heating control method for effective hyperthermia treatment of a brain tumor using the resonant cavity applicator with a segmented dielectric bolus. Thermal Med, 30: 41-53, 2014. 


\title{
Abstract in Japanese
}

\section{非接触ハイパーサーミア治療を目的とした 矩形型空胴共振器アプリケータの加温特性}

\author{
市島泰 $\alpha^{1} \cdot$ 新藤康 $弓_{厶}^{2} \cdot$ 井関祐 也 $^{3} \cdot$ 加藤和 $夫^{4}$ \\ 1明治大学大学院理工学研究科 \\ 2東洋大学理工学部機械工学科 \\ 3八戸工業高等専門学校機械システムデザインコース \\ 4明治大学理工学部機械情報工学科
}

\begin{abstract}
要 旨: 著者らは, これまでに円筒形状の空胴共振器を用いた非接触型の加温装置を提案している. 有限要素法による数值解析, この数值解析結果に基づく加温システムを試作し, 寒天ファントムおよび 動物の加温実験を通して，その有効性を実証してきた。しかしながら，これまでに提案した円筒型空胴 共振器を用いて人体腹部の深部腫瘍を加温しようとした場合, 空胴共振器内に収まっている目的部位以 外の領域をも加温する危険性が確認されていた。本研究では, これまでの円筒型空胴共振器アプリ ケータの欠点を補うために, 矩形状の空胴共振器を用いた矩形型空胴共振器アプリケータを提案してい る.アプリケータ形状を矩形状に改良することによって, 共振器内に収まる人体の範囲は少なくなり, そのため目的部位近傍のみを加温できる可能性があると考えられる。本論文では, 試作した矩形型空胴 共振器加温システムを用いて, 人体形状寒天ファントムを加温した結果を示し, 本手法の有用性を明ら かにする，まず，有限要素法を用いた数值解析から矩形型空胴共振器の形状および寸法を決定した，試 作した矩形型空胴共振器は高さ : $60 \mathrm{~cm}$, 横幅 : $70 \mathrm{~cm}$, 厚さ : $20 \mathrm{~cm}$ の矩形状である. 本試作加温シス テムは, 矩形型空胴共振器, 空胴共振器内に電磁波を励振するためのアンテナ, 共振周波数の自動探索 および自動インピーダンス整合機能を有するパワーゼネレータから構成されている. 次に, 本加温シス テムを用いて, 加温時間 30 分, 加温電力 $50 \mathrm{~W}$ とし, 人体形状寒天ファントムを対象とした加温実験 を実施した。そして, 加温直後の寒天中央断面での赤外線サーモ画像から，人体形状寒天ファントムの 加温ターゲットとした領域が集中的に加温されており, 最高温度上昇值は $5^{\circ} \mathrm{C}$ 程度であることが分かっ た。また, 他の領域にホットスポットは発生していないことを確認した。これらの結果から, 本加温シ ステムを用いることで, 矩形状の空胴共振器内に収まった人体深部領域を非接触状態で, 局所的に有効 加温し, それ以外の領域は異常加温されず, 安全かつ効果的に加温治療できる可能性を示した.
\end{abstract}

Thermal Med, 35[1]: 1-11, 2019. 